Bentham open
CrossMark
Content list available at: www.benthamopen.com/TOMCJ/
DOI: $10.2174 / 1874104501610010021$

RESEARCH ARTICLE

\title{
Synthesis, Characterization, Antimicrobial and Antioxidant Activities of The Homocyclotrimer Of 4-Oxo-4h-Thieno[3,4-C]Chromene-3- Diazonium Sulfate
}

Emmanuel Sopbue Fondjo, ${ }^{*}$, Djeukoua Dimo Kamal Sorel ${ }^{\mathrm{a}}$, Tamokou Jean-de-Dieu ${ }^{\mathrm{b}}$, Tsemeugne Joseph $^{\mathrm{a}}$, Kouamo Sylvian ${ }^{\mathrm{a}}$, Ngouanet Doriane ${ }^{\mathrm{a}}$, Chouna Jean Rodolphe ${ }^{\mathrm{a}}$, Nkeng-Efouet-Alango Pepin $^{\mathrm{a}}$, Kuiate Jules-Roger ${ }^{\mathrm{b}}$, Ngongang Ndjintchui Arnaud ${ }^{\mathrm{c}}$ and Sondengam Beibam Lucas ${ }^{\mathrm{d}}$

${ }^{a}$ Laboratory of Applied Synthetic Organic Chemistry, Department of Chemistry, Faculty of Science, University of Dschang, P.O. Box 67 Dschang, Republic of Cameroon

${ }^{b}$ Laboratory of Microbiology and antimicrobial Substances, Department of Biochemistry, Faculty of Science, University of Dschang, PO Box 067 Dschang, Republic of Cameroon

${ }^{c}$ Technical University of Munich, Department of Chemistry Lichtenbergstrasse 4, D-85747 Garching, Germany

${ }^{d}$ Department of Organic Chemistry, University of Yaounde I, P.O. Box 812 Yaounde, Republic of Cameroon

\begin{abstract}
The in situ formed 4-oxo-4H-thieno[3,4-c]chromene-3-diazonium sulfate (5) in the coupling reactions involving the parent 2 -aminothiophene (4) and various phenolic and arylamines' couplers, readily undergoes homocyclotrimerization at low temperature to afford in fairly good yield the first ever reported eighteen member ring heteroaromatic holigomer $\mathbf{6}$. Compound $\mathbf{6}$ was fully characterized by its elemental analysis, IR, UV-Vis, ${ }^{1} \mathrm{H}-\mathrm{NMR},{ }^{13} \mathrm{C}-\mathrm{NMR}$ and HRMS spectral data. The HMBC and HSQC techniques were used to ascertain the structural assignments. A comparative study on the antimicrobial and antioxidant activities of compounds $\mathbf{3 ,} \mathbf{4}$ and $\mathbf{6}$ was carried out to assess the SAR due to the transformations (from $\mathbf{3}$ to $\mathbf{6}$ via $\mathbf{4}$ ) on the tested compounds. It was found that compounds 6 and 4 were respectively the most active compounds against bacteria (MIC $=32-64 \mu \mathrm{g} / \mathrm{ml})$ and yeasts $(\mathrm{MIC}=16-64$ $\mu \mathrm{g} / \mathrm{ml}$ ). Compound $\mathbf{6}$ also showed high radical-scavenging activities and ferric reducing power when compared with vitamin $\mathrm{C}$ and BHT used as reference antioxidants.
\end{abstract}

Keywords: 2-aminothiophene, Azo compounds, Antimicrobial, Antioxidant, Coumarin, Homocyclotrimerization, Holigomer, SAR.

\section{INTRODUCTION}

As a result of the dramatic increase in microbial infections, serious attention has been directed in recent years towards the discovery and development of new antimicrobial drugs.

In medicinal chemistry, thiophene derivatives have been well known for their therapeutic applications. A review of the recent literature showed that many effective antimicrobial agents contain an heterocyclic moiety within their structure [1,2] with special emphasis on those agents incorporating a thiophene moiety [3 - 7]. The thiophene ring system is notably a structural component of the commercial imidazole antifungal agent sertaconazole [8]. In addition, the antimicrobial profile of condensed thiophenes, particularly their thieno[2,3-d]pyrimidin-4-one analogues, is also well categorized in the literature [9 - 11].

Coumarin and its derivatives represent one of the most active classes of compounds possessing a wide spectrum of

\footnotetext{
* Address correspondence to this author at the Laboratory of Applied Synthetic Organic Chemistry, Department of Chemistry, Faculty of Science, University of Dschang, P.O. Box 67 Dschang, Republic of Cameroon; Tel: +237 677822491; E-mail: sopbue@yahoo.fr
} 
biological activity [12 - 18]. The interesting biological activity of these coumarins made these compounds attractive targets in organic synthesis.

Azo compounds constitute one of the largest classes of industrially synthesized organic compounds, potent in drug and cosmetics [19]. Azo dyes are used widely in dying textile fibers, biomedical studies, advanced applications in organic synthesis and high technological areas like lasers, liquid crystalline displays, electro-optical devices and ink jet printer [20 - 22] as well as shows variety of interesting biological activities including antibacterial [23 - 26] and pesticidal activities [27]. The azo dyes possess antiseptic and antiprotozoal properties and also promote wound healing.

Based on the above considerations, we investigated the synthesis of hybrid molecular architectures containing thiophene, coumarin, and azo moieties likely to combine the biological features of all the components.

\section{RESULTS AND DISCUSSION}

\section{Chemistry}

The starting 2-aminothiophene reagent 4 was prepared by applying the third version of the Gewald methodology $[28,29]$, whereby the first step of the procedure consisted of a Knoevenagel [30] condensation of 2-hydroxy-1acetonaphthon (1) with ethyl cyanoacetate (2) to give the fused benzocoumarin 3 (Scheme 1). In the second step of the reaction sequence, compound $\mathbf{3}$ was treated with elemental sulphur and ammonia as catalytic amine base to afford compound 4 in excellent yield as previously reported [31]. The melting point, as well as all the elemental and all the other spectroscopic data were in all respects comparable to those originally reported for this compound.

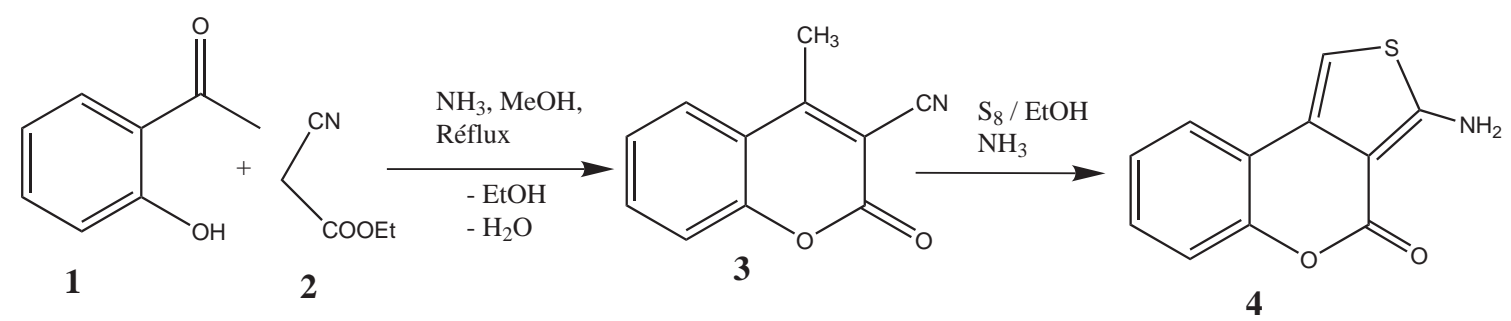

Scheme (1). Reaction sequences to compound 4.

The in situ formed intermediate thienyl diazonium sulphate 5 (Scheme 2) was generated from the diazotization of compound 4 using nitrosyl sulphuric acid at very low temperature $\left(0-5{ }^{\circ} \mathrm{C}\right)$. The freshly prepared diazonium solution was then coupled with 2-aminothiophene 4 . The resulted mixtures were worked-up as usual to yield the azo compound 6 (Scheme 2), which was fully characterized by its physical, elemental and spectroscopic data.

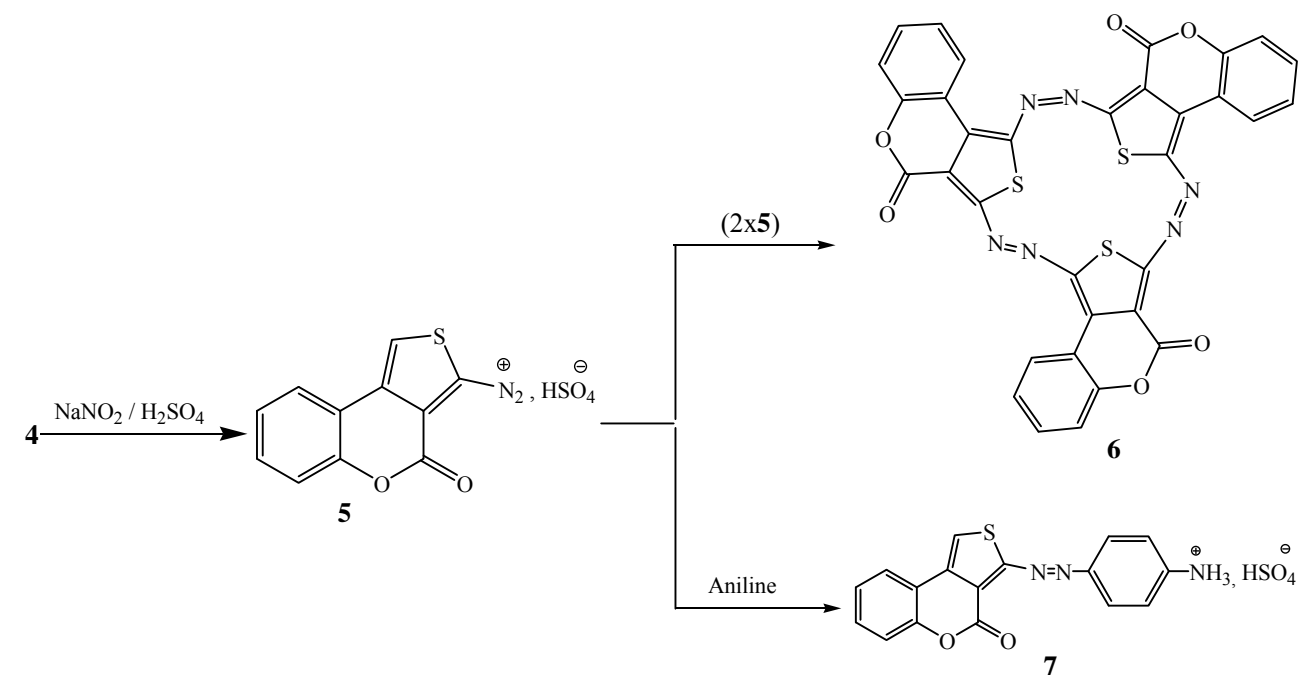

Scheme (2). Reaction sequences to compounds 6. 
Compound 6 was obtained as green yellowish powder with a sharp melting point at $213.5 \mathrm{C}$. Its UV-visible spectrum recorded in DMSO, showed absorptions in the range $212-500 \mathrm{~nm}$, in agreement with the highly conjugated $(18 \pi)$-electrons of the heteroaromatic chain, partly extended to the three annelated benzene rings. This also justified the strong bathochromic effect of the main absorption bands from the starting 2-aminothiophene compound 4 into the final product 6.

On the IR-spectrum, the $\mathrm{Csp}^{2}-\mathrm{H}$ stretching frequencies due to the aromatic rings were observed around $2950 \mathrm{~cm}^{-1}$, whereas the combined strong absorption frequencies of the $\mathrm{C}=\mathrm{O}$ groups was exhibited around $1724 \mathrm{~cm}^{-1}$. Strong to medium size stretching frequencies of the benzenic and thiophenic $\mathrm{C}=\mathrm{C}$ bonds were exhibited at 1677 and $1588 \mathrm{~cm}^{-1}$, and in the range 1544-1500 $\mathrm{cm}^{-1}$ respectively. The ortho disubstitution pattern of the benzene rings was characterized by the strong absorption band appearing at $767 \mathrm{~cm}^{-1}$. The presence of the $-\mathrm{N}=\mathrm{N}-$ bonds was confirmed by a medium size band at $1490 \mathrm{~cm}^{-1}$.

The structure of compound $\mathbf{6}$ is further strongly supported by its HRMS ESI ${ }^{+}$-mode, which shows the pseudo molecular ion peak at $\mathrm{m} / \mathrm{z} 685(29 \%)$ corresponding to $[\mathrm{M}+\mathrm{H}]$; this is in full agreement with the combustion analysis data. The mass spectrum of compound 6 contained fragments ions at m/z $640(3 \%), 596(1 \%), 552(3 \%), 659(8 \%), 627$ (1\%), $620(1 \%), 588(1 \%), 532(1 \%), 628(1 \%), 600(1 \%), 572(2 \%), 544(1 \%), 516(40 \%), 484(1 \%), 452(1 \%)$ and $248(94 \%)$ which could be assigned to $\left[\mathrm{M}^{+}-\mathrm{CO}_{2}\right],\left[\mathrm{M}^{+}-2 \mathrm{CO}_{2}\right],\left[\mathrm{M}^{+}-3 \mathrm{CO}_{2}\right],\left[\mathrm{M}^{+}-\mathrm{N}_{2}\right],\left[\mathrm{M}^{+}-2 \mathrm{~N}_{2}\right],\left[\mathrm{M}^{+}-2 \mathrm{~S}\right],\left[\mathrm{M}^{+}-3 \mathrm{~S}\right]$, $\left[\mathrm{M}^{+}-3 \mathrm{~S}-2 \mathrm{~N}_{2}\right],\left[\mathrm{M}^{+}-2 \mathrm{CO}\right],\left[\mathrm{M}^{+}-3 \mathrm{CO}\right],\left[\mathrm{M}^{+}-3 \mathrm{CO}-\mathrm{N}_{2}\right],\left[\mathrm{M}^{+}-3 \mathrm{CO}-2 \mathrm{~N}_{2}\right],\left[\mathrm{M}^{+}-3 \mathrm{CO}-3 \mathrm{~N}_{2}\right],\left[\mathrm{M}^{+}-3 \mathrm{CO}-3 \mathrm{~N}_{2}-\mathrm{S}\right],\left[\mathrm{M}^{+}-3 \mathrm{CO}\right.$ $\left.-3 \mathrm{~N}_{2}-2 \mathrm{~S}\right]$ and $\left[\mathrm{M}^{+}-3 \mathrm{CO}-3 \mathrm{~N}_{2}-3 \mathrm{~S}-\mathrm{C}_{10} \mathrm{H}_{4}\right]$. The Scheme 3 below rationalizes the formation of the fragments at $m / z 516$ (40\%), $437(65 \%), 393(19 \%)$ and $339(42 \%)$ respectively.

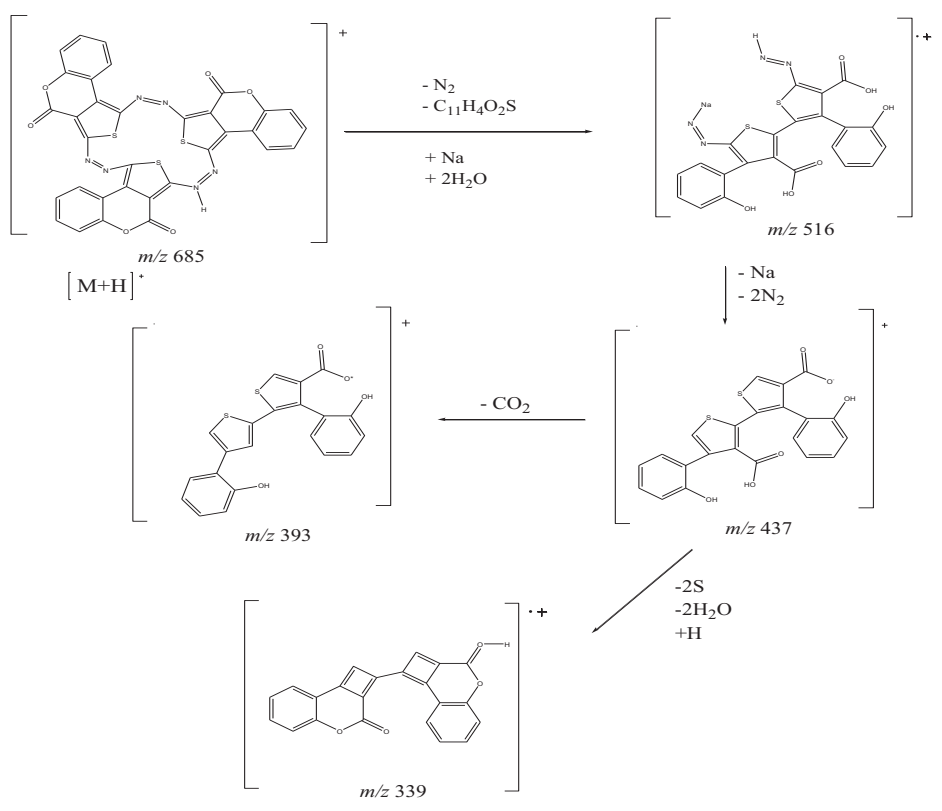

Scheme (3). Some important ESI+-mode fragments of compound 6.

The absence of thiophenic protons in the ${ }^{1} \mathrm{H}-\mathrm{NMR}$ spectrum of compound $\mathbf{6}$ which normally appear in the range 6.5-7.2 ppm, indicated that these protons were involved in the cyclisation process. The ${ }^{1} \mathrm{H}-\mathrm{NMR}$ spectrum showed four sets of aromatic $\mathrm{Csp}^{2}-\mathrm{H}$ protons at $8.73(\mathrm{dd} ; J=8 ; 1.6 \mathrm{~Hz} ; \mathrm{H}-7, \mathrm{H}-21$ et H-35), 7.85 (ddd; $J=8.4 ; 6.4 ; 1.6 \mathrm{~Hz}$; H-9, $\mathrm{H}-23$ et H-37), 7.53 (dd; $J=5.2 ; 1.2 \mathrm{~Hz} ; \mathrm{H}-10, \mathrm{H}-24$ et $\mathrm{H}-38)$ and 7.51 ppm (ddd; $J=8.1 ; 7.2 ; 1.2 \mathrm{~Hz} ; \mathrm{H}-8, \mathrm{H}-22$ et $\mathrm{H}-36)$. The presence of the signal of four protons instead of twelve could be explained by the symmetric nature of compound 6.

The ${ }^{13} \mathrm{C}$-NMR spectrum of compound $\mathbf{6}$ exhibited eleven signals instead of thirty three as deduced from the molecular formula. The symmetrical nature of compound $\mathbf{6}$ could also explain this observation. The ${ }^{13} \mathrm{C}-\mathrm{NMR}$ spectrum consisted of 11 signals among which four $[135.5$ (C-9, C-23 and C-37); 128.9 (C-7, C-21 and C-35); 125.4 (C-8, C-22 and C-36) and 117.1 (C-10, C-24 and C-38)] could be assigned to tertiary $\mathrm{Csp}^{2}-\mathrm{H}$ aromatic carbons. The remaining other seven signals [184.9 (C-13, C-27 and C-41); 154.9 (C-11, C-25 and C-39); 153.7 (C-5, C-19 and C-33); 153.5 
(C-14, C-28 and C-42); 147.8 (C-1 ; C-15 and C-29); 119.9 (C-6, C-20 and C-34) and 114.9 (C-4, C-18 and C-32)] were attributed to the quaternary carbon atoms by comparing the experimental values with the simulated ones.

A remarkable feature in the ${ }^{13} \mathrm{C}$-NMR spectrum of this compound is the intense downfield shifts $(\Delta \delta=19.2 \mathrm{ppm})$ of the $\delta_{\mathrm{C}=\mathrm{O}}$ of the carbonyl of the coumarin rings respectively from $165.70 \mathrm{ppm}$ in the parent thiophene substrate 4 [31] to 184.9 ppm in the coupling product. This abnormally high value could be explained by the strong diamagnetic anisotropy $[32,33]$ of the $18 \pi$-electrons of the heteroaromatic ring system comprising the alternating three fused thiophene rings and the alternating three $-\mathrm{N}=\mathrm{N}-$ bonds.

It should be mentioned that, in cyclic conjugated systems such as annulenes, the effect of ring currents is particularly illustrative. In fact, with $(4 n+2) \pi$-electrons the annulenes exhibit aromatic character. For example (18)annulene $[32,33]$ exhibits a similar ring current as found in six membered aromatic or heteroaromatic compounds. In these cases too, the magnetic field induced by the circulation of $\pi$-electrons opposes the applied magnetic field in the center of the ring and reinforces it around the periphery. As a result, the protons and carbons lying inside the ring of (18)-annulenes are strongly shielded while those on the outer side are strongly deshielded. In the case of compound $\mathbf{6}$, the 18-membered heteroaromatic skeleton is planar and is assumed to have a similar behavior in the applied magnetic field as with normal (18)-annulenes.

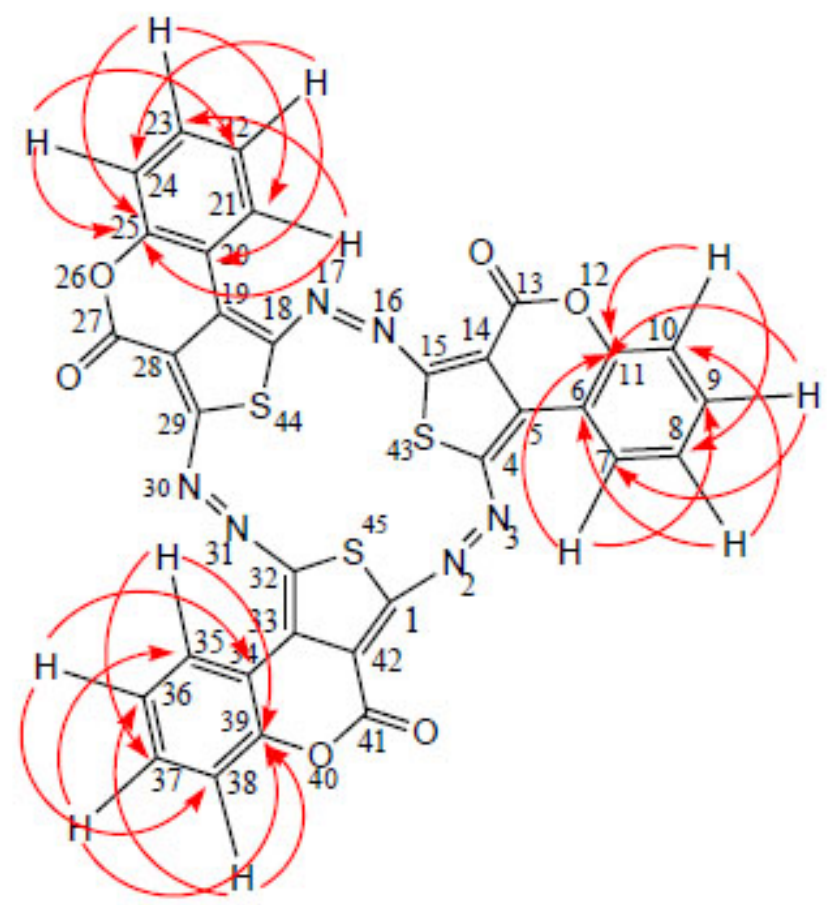

Fig. (1). HMBC interactions in compound 6.

Table 1. HSQC and HMBC interactions and ${ }^{1} \mathrm{H}$ and ${ }^{13} \mathrm{C}$ chemical shifts $\delta$ in compound 6 in DMSO-d as $_{6}$ the solvent $\left(25{ }^{\circ} \mathrm{C}\right)$.

\begin{tabular}{|c|c|c|c|}
\hline C-atom & $\boldsymbol{\delta}^{13} \mathbf{C}$ & HSQC $(\mathbf{H} \rightarrow \mathbf{C})$ & HMBC $(\mathbf{H} \rightarrow \mathbf{C})$ \\
\hline 6,20 and 34 & 119.9 & & $7.51(\mathrm{H}-8, \mathrm{H}-22, \mathrm{H}-36)$ \\
\hline 14,28 and 42 & 153.5 & & \\
\hline 1,15 and 29 & 147.8 & & $8.73(\mathrm{H}-7, \mathrm{H}-21, \mathrm{H}-35), 7.85(\mathrm{H}-9, \mathrm{H}-23, \mathrm{H}-37), 7.53(\mathrm{H}-10, \mathrm{H}-24$, \\
\hline 13,27 and 41 & 184.9 & & $7.51(\mathrm{H}-8, \mathrm{H}-22, \mathrm{H}-36)$ \\
\hline 11,25 and 39 & 154.9 & & $8.73(\mathrm{H}-7, \mathrm{H}-21, \mathrm{H}-35)$ \\
\hline 10,24 and 38 & 117.1 & $7.53(\mathrm{H}-10, \mathrm{H}-24, \mathrm{H}-38)$ & $7.53(\mathrm{H}-10, \mathrm{H}-24, \mathrm{H}-38)$ \\
\hline 9,23 and 37 & 135.5 & $7.85(\mathrm{H}-9, \mathrm{H}-23, \mathrm{H}-37)$ & $7.85(\mathrm{H}-9, \mathrm{H}-23, \mathrm{H}-37)$ \\
\hline 8,22 and 36 & 125.4 & $7.51(\mathrm{H}-8, \mathrm{H}-22, \mathrm{H}-36)$ & \\
\hline 7,21 and 35 & 128.9 & $8.73(\mathrm{H}-7, \mathrm{H}-21, \mathrm{H}-35)$ & \\
\hline 4,18 and 32 & 114.9 & & \\
\hline
\end{tabular}




(Table 1) contd.....
\begin{tabular}{|c|c|c|c|}
\hline $\mathbf{C}$-atom & $\boldsymbol{\delta}^{13} \mathbf{C}$ & HSQC $(\mathbf{H} \rightarrow \mathbf{C})$ & HMBC $(\mathbf{H} \rightarrow \mathbf{C})$ \\
\hline 5,19 and 33 & 153.7 & & \\
\hline
\end{tabular}

The HMBC spectra [34, 35] were very helpful for locating the tertiary and quaternary carbons by identifying the various protons interacting with them through two-bond $\left({ }^{2} J_{\mathrm{CH}}\right)$, three-bond $\left({ }^{3} J_{\mathrm{CH}}\right)$ and occasionally four-bond $\left({ }^{4} J_{\mathrm{CH}}\right)$ couplings as displayed in Table 1 and Fig. (1). Additionally, the HSQC experiments were performed in order to assign accurately the direct connectivities of the aromatic sp2 carbons to the corresponding protons.

\section{Biology}

\section{Antimicrobial Activity}

The results of the antimicrobial activity are summarized in Table 2. Compounds $\mathbf{4}$ and $\mathbf{6}$ displayed weak to moderate antibacterial and antifungal activities $(\mathrm{MIC}=16-64 \mu \mathrm{g} / \mathrm{ml})$. Compounds 4 and $\mathbf{6}$ were respectively the most active compounds against bacteria $(\mathrm{MIC}=32-64 \mu \mathrm{g} / \mathrm{ml}$ ) and yeasts $(\mathrm{MIC}=16-64 \mu \mathrm{g} / \mathrm{ml})$. No activity was noticed for compound 3 against all the tested microorganisms (results not shown). Previous studies have shown antibacterial [36] and antifungal [37] activities of azo compounds. The lowest MIC value of $16 \mu \mathrm{g} / \mathrm{mL}$ was recorded on Candida albicans with compound 4 while the lowest MBC value of $32 \mu \mathrm{g} / \mathrm{mL}$ was obtained on Shigella flexneri and Escherichia coli with compound 6 and on Candida albicans and Candida parapsilosis with compound 4 . However, the highest MIC and MMC values of $128 \mu \mathrm{g} / \mathrm{mL}$ were recorded on Candida glabrata with compound 6. A lower MMC/MIC $(\leq 4)$ value signifies that a minimum amount of compound is used to kill the microbial species, whereas, a higher MMC/MIC $(>4)$ value signifies the use of comparatively more amount of sample for the control of any microorganism [38]. The findings of the present study suggest that compounds $\mathbf{4}$ and $\mathbf{6}$ possess microbicidal activity against the sensitive microorganisms.

Table 2. Antimicrobial activity (MIC and MMC in $\mu \mathrm{g} / \mathrm{mL}$ ) of compounds 4 and 6 against bacterial and yeast species.

\begin{tabular}{|c|c|c|c|c|c|c|c|c|c|c|c|c|}
\hline Compounds & Inhibition Parameters & ST & SF & $\mathbf{E F}$ & $\mathbf{K P}$ & EC & STB & STA & CPn & $\mathbf{C P}$ & CA & CG \\
\hline \multirow[t]{3}{*}{6} & MIC & 64 & 32 & 64 & 32 & 32 & 64 & 32 & 64 & 64 & 32 & 128 \\
\hline & $\mathrm{MMC}$ & 64 & 32 & 64 & 64 & 32 & 64 & 64 & 64 & 64 & 64 & 128 \\
\hline & $\mathrm{MMC} / \mathrm{MIC}$ & 1 & 1 & 1 & 2 & 1 & 1 & 2 & 1 & 1 & 2 & 1 \\
\hline \multirow[t]{3}{*}{4} & MIC & $>256$ & 32 & $>256$ & $>256$ & 64 & $>256$ & 64 & 32 & 32 & 16 & 64 \\
\hline & MMC & nd & 64 & nd & nd & 64 & nd & 64 & 64 & 32 & 32 & 64 \\
\hline & MMC/MIC & nd & 2 & nd & nd & 1 & nd & 1 & 2 & 1 & 2 & 1 \\
\hline \multirow[t]{3}{*}{ *Standard drugs } & MIC & 8 & 2 & 2 & 2 & 8 & 8 & 1 & 4 & 2 & 4 & 2 \\
\hline & MMC & 8 & 4 & 4 & 4 & 8 & 8 & 2 & 4 & 8 & 4 & 4 \\
\hline & MMC/MIC & 1 & 2 & 2 & 2 & 1 & 1 & 2 & 1 & 4 & 1 & 2 \\
\hline
\end{tabular}

Compound 3 was not active at concentrations up to $256 \mu \mathrm{g} / \mathrm{ml}$; nd: not determined; * ciprofloxacin and nystatin were used as standard drugs for bacteria and yeasts respectively; MIC: Minimum inhibitory concentration; MMC: minimum microbicidal concentration; ST: Salmonella typhi ATCC6539; SF: Shigella flexneri ; EF: Enterococcus faecalis ATCC10541; KP: Klebsiella pneumoniae ATCC13883; EC: Escherichia coli ATCC11775; STB: Salmonella paratyphi B; STA: Salmonella paratyphi A ; CPn: Candida parapsilosis; CP: Candida parapsilosis ATCC 22019; CA: Candida albicans ATCC 9002; CG: Candida glabrata IP35.

\section{Ferric Reducing Antioxidant Power (FRAP)}

The FRAP assay measures the ability of an antioxidant to reduce ferric (III) to ferrous (II) in a redox-linked colourimetric reaction that involves single electron transfer [39]. The reducing power of a compound serves as a significant indicator of its potential antioxidant activity. The results of the reducing power assay of synthesized compounds are summarized in Fig. (2). All the investigated compounds showed dose-dependent reducing power. Interestingly, compound $\mathbf{4}$ showed the lowest reducing power, while compound $\mathbf{6}$ exhibited the highest reducing power at the different concentrations tested. The antioxidant power of compound $\mathbf{6}$ is almost equal to that of butylated hydroxytoluene (BHT) used as standard antioxidant. 


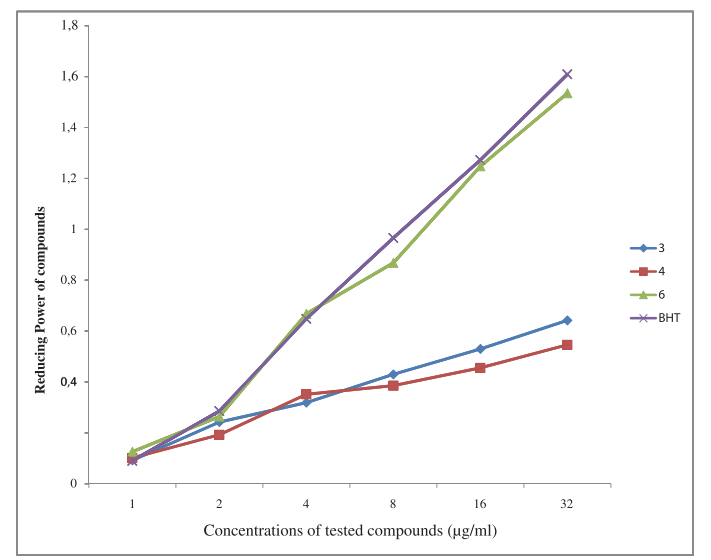

Fig. (2). Reducing power activities of the tested compounds as well as BHT.

\section{DPPH Free Radical Scavenging Activity}

The concentrations which decreased by $50 \%$ the absorbance of DPPH $\left(\mathrm{EC}_{50}\right)$ are presented in Fig. (3). These results showed that the compound $\mathbf{4}$ had the highest $\mathrm{EC}_{50}$ (i.e., the lowest activity) while compound $\mathbf{6}$ had the lowest $\mathrm{EC}_{50}$ (i.e. had the highest activity). The DPPH free radical scavenging activity of compound $\mathbf{6}$ was comparable to that of the standard antioxidant vitamin C. These results corroborate the FRAP assay, where this compound exhibited the best antioxidant activity. Previous study has shown strong antioxidant activity of azo compounds performed by using DPPH free radical scavenging assay and metal chelating method [40]. The results of the antioxidant study show that these azo compounds may have great relevance in the prevention and therapies of diseases in which oxidants or free radicals are implicated [40].

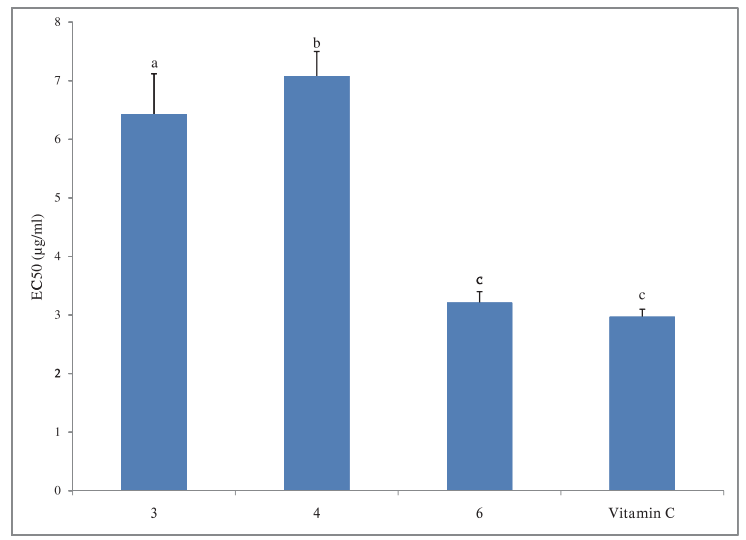

Fig. (3). Equivalent concentrations of test compounds scavenging 50\% of DPPH radical (EC50)

From the structure activity relationship (SAR) point of view, one can logically say that, the thiolation of the carbonitrile 3 at its methyl group, followed by the intramolecular heterocyclisation and aromatization of the fused five member ring to afford compound $\mathbf{4}$ - resulted into the significant improvement of the antibacterial and antifungal activities of the latter as compared to its precursor. However, these chemical transformations have slightly reduced the antioxidant activity of $\mathbf{4}$ compare to that of compound $\mathbf{3}$.

Furthermore, the diazotization of compound $\mathbf{4}$, which led to the homocyclotrimerization of the in situ formed thienyl diazonium salts $\mathbf{5}$, resulted in enhancing significantly and globally the evaluated biological activities of the final product 6. The results are in accordance with other reports in the literature [41, 42], which showed the importance of thiolation and diazotization in antimicrobial and antioxidant activities.

\section{MATERIALS AND METHODS}

\section{General Information}

All Melting points are corrected and were determined with a STUART SCIENTIFIC Melting Point Apparatus 
Model SMP3. The TLCs were carried out on Eastman Chromatogram Silica Gel Sheets $(13181 ; 6060)$ with fluorescent indicator. A mixture of ethyl acetate and methylene chloride (1:1) was used as eluent and iodine was used as revelator for the chromatograms. The IR spectra were measured with a Fourier Transform Infrared spectrometer Brucker Alpha. The UV spectra were recorded with a JENWAY 6715 UV-Vis Spectrophotometer. Combustion analyses were carried out with a C, H, N, S Euro EA from Hekatech company, their results were found to be in good agreement $( \pm 0.3 \%)$ with the calculated values. EIMS spectra were recorded on a double focusing mass spectrometer (Varian MAT 311A). ${ }^{1} \mathrm{H}-$ NMR spectra were recorded in DMSO- $\mathrm{d}_{6}$ on a Bruker DRX spectrometer operating at $500 \mathrm{MHz} .{ }^{13} \mathrm{C}-\mathrm{NMR}$ spectra were recorded in DMSO- $\mathrm{d}_{6}$ on a Bruker DRX spectrometer operating at $125 \mathrm{MHz}$. TMS was used as internal reference.

\section{Preparation of the Reagents and Starting Materials}

All the reagents mentioned in this work were purchased from Aldrich and Fluka and were used without further purification. Starting material 4 has been prepared according to literature procedures as published earlier [31a].

\section{3-Amino-4H-thieno [3,4-c] [1] Benzopyran-4-one (4)}

A mixture of 2-ceto-4-methyl-2H- [1] benzopyran-3-carbonitrile ( $4.65 \mathrm{~g})$ and sulphur (1.22 g, in excess) in ethanol $(30 \mathrm{ml})$ was stirred using a magnetic plate shaker thermostated at $45^{\circ} \mathrm{C}$. Ammonia $(6 \mathrm{ml})$ was added drop wise during the first $10 \mathrm{~min}$ of the reaction. After $7 \mathrm{~h}$ of reaction, the resulting precipitate $(5.08 \mathrm{~g}, 93 \%)$ was collected by filtration, washed with distilled water and recrystallised in benzene to yield a yellow powder, mp $195-196{ }^{\circ} \mathrm{C}\left(\mathrm{Lit} .18198-199{ }^{\circ} \mathrm{C}\right.$, from benzene); IR (potassium bromide): 3449 (-NH2); $1687(\mathrm{C}=\mathrm{O}) ; 1603$ and $1547(\mathrm{C}=\mathrm{C}) ; 1224(\mathrm{C}-\mathrm{O}) ; 1 \mathrm{H}$ NMR: 7.87 $(1 \mathrm{H} ; \mathrm{dd} ; \mathrm{J}=8.0 ; 1.5 \mathrm{~Hz} ; \mathrm{H}-8) ; 7.36(1 \mathrm{H} ; \mathrm{ddd} ; \mathrm{J}=8.0 ; 7.4 ; 1.8 \mathrm{~Hz}$; H-6); 7.22-7.17 (2H; m; H-7 and H-5); $7.78(2 \mathrm{H} ; \mathrm{br}$ s; NH2); 6.89 (1H; s; thiophenic H); 13C(1H) NMR: 158.98 (C-2); 118.05 (C-2a); 166.70 (C-3); 151 (C-4a); 97.54 (C-5); 124.39 (C-6); 117.09 (C-7); 123.91 (C-8); 130.90 (C-8a); 98.07 (C-8b); 129.26 (C-9); ms: (EI) m / z (\%) 217 (M+; 100\%). Anal. Calcd for $\mathrm{C}_{11} \mathrm{H}_{7} \mathrm{NO}_{2} \mathrm{~S}$ C: $60.83 ; \mathrm{H}, 3.23 ; \mathrm{N}, 6.45 ; \mathrm{S}, 14.75$. Found $\mathrm{C}, 61.17 ; \mathrm{H}, 3.36$; N, 6.49; S, 14.45 .

\section{Preparation of Diazonium Salt Solution}

Dry sodium nitrite $(2.07 \mathrm{~g}, 3 \mathrm{mmol})$ was slowly added over a period of 30 minutes to concentrated sulphuric acid $(10 \mathrm{~mL})$ with occasional stirring. The solution was cooled to $0-5^{\circ} \mathrm{C}$. Compound $4(0.22 \mathrm{~g}, 1 \mathrm{mmol})$ was dissolved in DMSO $(10 \mathrm{~mL})$ and cooled to $0-5{ }^{\circ} \mathrm{C}$. The nitrosyl sulphuric acid solution was added to the solution of $\mathbf{4}$ and the temperature was maintained to $0-5^{\circ} \mathrm{C}$. The clear diazonium salt solution thus obtained consisting of the in situ formed intermediates $\mathbf{5}$, was used immediately in the coupling reactions.

\section{Procedure for the Preparation of the Coupling Product 6}

Aniline $(0.279 \mathrm{~g} ; 3 \mathrm{mmol})$ was dissolved in DMSO $(10 \mathrm{~mL})$ and then cooled in an ice-bath at $0-5{ }^{\circ} \mathrm{C}$. The diazonium solution of 4 previously prepared was added drop wise over 1 hour, and then $15 \mathrm{~mL}$ of sodium acetate solution (10\%) was added in the mixture. The solid precipitate consisting of the previously reported [31b] (4H)-2-(pAminophenylazo)thieno[3,4-c]chromen-4-one hydrogen sulfate (7) was collected on a filter and crystallised from methanol to give the corresponding thienyl azo aryl dye. Work up of the resulted filtrate gave compound $\mathbf{6}$ in average yield of $11 \%$.

$12,26,40$-trioxa-43,44,45-trithia-2,3,16,17,30,31-hexaazadecacyclo $\left[30 \cdot 10 \cdot 1 \cdot 1^{4,15} \cdot 1^{18,29} \cdot 0^{5,14} \cdot 0^{6,11} \cdot 0^{19,28} \cdot 0^{20,25} \cdot 0^{33,42} \cdot 0^{34,39}\right]$ pentatetraconta-1(42),2,4,6,8,10,14,16,18,20,22,24,28,30,32, 34, 36,38-octadecaene-13,27,41-trione (6).

Compound 6 (124 mg, $11 \%$ ) was obtained as green yellowish powder. m.p. $213.5^{\circ} \mathrm{C}$; $\mathrm{Rf}=0.43$ in $\mathrm{CH}_{2} \mathrm{Cl}_{2} / \mathrm{AcOEt}$ $50 \% \mathrm{v} / \mathrm{v}$; IR (potassium bromide): $2588(=\mathrm{C}-\mathrm{H}), 1724(\mathrm{C}=\mathrm{O}), 1677-1588\left(\mathrm{C}_{\mathrm{Ar}}=\mathrm{C}_{\mathrm{Ar}}\right), 1544-1500$ (thiophenic $\left.\mathrm{C}=\mathrm{C}\right), 1490$ $(-\mathrm{N}=\mathrm{N}-), 767\left(=\mathrm{C}_{\mathrm{Ar}}-\mathrm{H}\right) \mathrm{cm}^{-1} ; \lambda \max$ (DMSO) (Log $\left.\varepsilon\right): 400$ (4.70), 282 (4.49), 229 (4.71); ${ }^{1} \mathrm{H}-\mathrm{NMR}$ (DMSO-d ${ }_{6}, 500$ MHz) $\delta 8.73(\mathrm{dd}, 3 \mathrm{H}, 7-\mathrm{H}, 21-\mathrm{H}$ and $35-\mathrm{H}, J=8$ and $1.6 \mathrm{~Hz}$ ), 7.85 (ddd, 3H, 9-H, 23-H and 37- $\mathrm{H}, J=8.4,6.4$ and 1.6 $\mathrm{Hz}$ ), $7.53(\mathrm{dd}, 3 \mathrm{H}, 10-\mathrm{H}, 24-\mathrm{H}$ and $38-\mathrm{H}, J=5.2$ and $1.2 \mathrm{~Hz}$ ), 7.51 (ddd, $3 \mathrm{H}, 8-\mathrm{H}, 22-\mathrm{H}$ and 36- $\mathrm{H}, J=8.1,7.2$ and 1.2 Hz). ${ }^{13} \mathrm{C}\left({ }^{1} \mathrm{H}\right)-\mathrm{NMR}\left(\mathrm{DMSO}_{6}, 125 \mathrm{MHz}\right) \delta 135.5$ (C-9, C-23 and C-37), 128.9 (C-7, C-21 and C-35), 125.4 (C-8, C-22 and C-36), 117.1 (C-10, C-24 and C-38), 184.9 (C-13, C-27 and C-41), 153.7 (C-5, C-19 and C-33), 153.5 (C-14, C-28 and C-42), 147.8 (C-1, C-15 and C-29), 119.9 (C-6, C-20 and C-34), 114.9 (C-4, C-18 and C-32), 154.9 (C-11, C-25 and C-39); ms: (ESI $\left.{ }^{+}\right) m / z(\%) 685$ (29), 516 (40), 437 (65), 393 (19), 339 (42), 248 (94). Anal. Calcd. for $\mathrm{C}_{33} \mathrm{H}_{12} \mathrm{~N}_{6} \mathrm{O}_{6} \mathrm{~S}_{3}: \mathrm{C}, 57.89 ; \mathrm{H}, 1.77 ; \mathrm{N}, 12.27 ; \mathrm{S}, 14.05$. Found C, 57.82; H, 1.75; N, 12.30; S, 14.11. 


\section{BIOLOGICAL ASSAY}

\section{Microorganisms}

The studied microorganisms were reference strains (from the ATCC) of Salmonella typhi ATCC6539, Enterococcus faecalis ATCC10541, Escherichia coli ATCC11775, Klebsiella pneumoniae ATCC13883, Candida parapsilosis ATCC 22019, C. albicans ATCC 9002. Also, included were four clinical isolates of Shigella flexneri, Salmonella paratyphi B, Salmonella paratyphi A, and Candida parapsilosis collected from Pasteur Centre (Yaounde-Cameroon) and one clinical strain of Candida glabrata IP35 obtained from Pasteur Institute (Paris-France). The bacterial and fungal species were maintained on agar slant at $+4{ }^{\circ} \mathrm{C}$ and subcultured at $37^{\circ} \mathrm{C}$ on nutrient agar (NA, Conda, Madrid, Spain) and Sabouraud Dextrose Agar (SDA, Conda) slants respectively, prior to any antimicrobial test.

\section{Determination of Minimum Inhibitory Concentration (MIC) and Minimum Microbicidal Concentration (MMC)}

MIC values were determined by a broth micro-dilution method as described earlier [43] with slight modifications. Each test sample was dissolved in dimethylsulfoxide (DMSO) and the solution was then added to Mueller Hinton Broth (MHB) for bacteria or Sabouraud Dextrose Broth (SDB) for yeasts to give a final concentration of $1024 \mu \mathrm{g} / \mathrm{mL}$. This was serially diluted twofold to obtain a concentration range of $0.25-1024 \mu \mathrm{g} / \mathrm{mL}$. Then, $100 \mu \mathrm{L}$ of each concentration were added in each well (96-well microplate) containing $95 \mu \mathrm{L}$ of $\mathrm{MHB}$ or SDB and $5 \mu \mathrm{L}$ of inoculum for final concentrations varying from $0.25-512 \mu \mathrm{g} / \mathrm{mL}$. The inoculum was standardized at $1.5 \times 10^{6} \mathrm{CFU} / \mathrm{mL}$ by adjusting the optical density to 0.1 at $600 \mathrm{~nm}$ using a JENWAY $6105 \mathrm{UV} / \mathrm{Vis}$ spectrophotometer. The final concentration of DMSO in each well was $<1 \%$ [preliminary analyses with $1 \%(\mathrm{v} / \mathrm{v})$ DMSO did not inhibit the growth of the test organisms]. The negative control well consisted of $195 \mu \mathrm{L}$ of MHB or SDB and $5 \mu \mathrm{L}$ of the standard inoculum. The plates were covered with sterile lids, then agitated to mix the contents of the wells using a plate shaker and incubated at $37^{\circ} \mathrm{C}$ for $24 \mathrm{~h}$ (for bacteria) or for $48 \mathrm{~h}$ (for yeasts). The assay was repeated three times. The MIC values of samples were determined by adding $50 \mu \mathrm{L}$ of a $0.2 \mathrm{mg} / \mathrm{mL} p$-iodonitrotetrazolium violet solution followed by incubation at $37^{\circ} \mathrm{C}$ for $30 \mathrm{~min}$. Viable microorganisms reduced the yellow dye to a pink color. MIC values were defined as the lowest sample concentrations that prevented this change in color indicating a complete inhibition of microbial growth. For the determination of MMC values, a portion of liquid $(5 \mu \mathrm{L})$ from each well that showed no growth of microorganism was plated on Mueller Hinton Agar or SDA and incubated at $37{ }^{\circ} \mathrm{C}$ for $24 \mathrm{~h}$ (for bacteria) or $37{ }^{\circ} \mathrm{C}$ for $48 \mathrm{~h}$ (for yeasts). The lowest concentrations that yielded no growth after this subculturing were taken as the MMC values [44]. Ciprofloxacin (Sigma-Aldrich, Steinheim, Germany) and nystatin (Merck, Darmstadt, Germany) were used as positive controls for bacteria and yeasts, respectively.

\section{Ferric Reducing Antioxidant Power (FRAP) Assay}

The ferric reducing power was determined by the $\mathrm{Fe}^{3+}-\mathrm{Fe}^{2+}$ transformation in the presence of of compounds $\mathbf{3}, \mathbf{4}$ and 6. The $\mathrm{Fe}^{2+}$ was monitored by measuring the formation of Perl's Prussian blue at $700 \mathrm{~nm}$. The method reported by Padmaja et al. [45] was used, with slight modification. Briefly, volumes of test solutions were mixed with $500 \mu \mathrm{L}$ of phosphate buffer $\left(\mathrm{pH} \mathrm{6.6)}\right.$ ) and $500 \mu \mathrm{L}$ of $1 \%$ potassium ferricyanide and incubated at $50{ }^{\circ} \mathrm{C}$ for $20 \mathrm{~min}$. Then $500 \mu \mathrm{L}$ of $10 \%$ trichloroacetic acid was added to the mixture and centrifuged at $3000 \mathrm{rpm}$ for $10 \mathrm{~min}$. Supernatant $(500 \mu \mathrm{L})$ was diluted with $500 \mu \mathrm{L}$ of water and shaken with $100 \mu \mathrm{L}$ of freshly prepared $0.1 \%$ ferric chloride. The absorbance was measured at $700 \mathrm{~nm}$. Butylated hydroxytoluene (BHT) was used as a positive control. Increased absorbance of the reaction mixture indicates higher reduction capacity of the compounds.

\section{ANTIOXIDANT ASSAY}

\section{DPPH Free radical Scavenging Assay}

The free radical scavenging activity of compounds 3, 4 and $\mathbf{6}$ was evaluated according to described methods [38]. Briefly, the test samples, prior dissolved in DMSO (SIGMA) beforehand, were mixed with a $20 \mathrm{mg} / 1$ 2,2-diphenyl-1picryl-hydrazyl (DPPH) methanol solution, to give final concentrations of 1, 10, 25, 50, 75, 100, and $200 \mu \mathrm{g} / \mathrm{mL}$. After $30 \mathrm{~min}$ at room temperature, the absorbance values were measured at $517 \mathrm{~nm}$ and converted into percentage of antioxidant activity. L-ascorbic acid was used as a standard control. The percentage of decolouration of DPPH (\%) was calculated as follows: 


\section{(Absorbance of control - Absorbance of test sample) x 100}

\section{$\%$ decolouration of DPPH $=\frac{\text { Absorbance of control }}{\text { (Absor }}$}

The radical scavenging percentages were plotted against the logarithmic values of the concentration of test samples and a linear regression curve was established in order to calculate the $\mathrm{EC}_{50}(\mu \mathrm{g} / \mathrm{ml})$, which is the amount of sample necessary to inhibit by $50 \%$ the absorbance of free radical DPPH. All the analyses were carried out in triplicate.

\section{Statistical Analysis}

Data were analyzed by one-way analysis of variance followed by Waller-Duncan Post Hoc test. The experimental results were expressed as the mean \pm Standard Deviation (SD). Differences between groups were considered significant when $p<0.05$. All analyses were performed using the Statistical Package for Social Sciences (SPSS, version 12.0) software.

\section{CONCLUSION}

The findings described in the present work have confirmed the synthetic potential of 2-aminothiophenes and the very high reactivity of the title diazonium salt $\mathbf{5}$. In addition to the normally anticipated coupling products described the previous investigations, this reactions' intermediate further reacts with itself to give the homocoupling product $\mathbf{6}$. Compounds 6 and 4 were respectively the most active compounds against bacteria (MIC $=32-64 \mu \mathrm{g} / \mathrm{ml}$ ) and yeasts $(\mathrm{MIC}=16-64 \mu \mathrm{g} / \mathrm{ml})$. Compound 6 also showed high radical-scavenging activity and ferric reducing power when compared with vitamin $\mathrm{C}$ and BHT used as reference antioxidants suggesting that this compound could be used as a tool for the design of novel antioxidant derivatives.

\begin{tabular}{|c|c|c|}
\hline \multicolumn{3}{|c|}{ ABBREVIATIONS } \\
\hline${ }^{13} \mathrm{C}-\mathrm{NMR}$ & $=$ & Thirtheen Carbon Nuclear Magnetic Resonance \\
\hline${ }^{1} \mathrm{H} N M R$ & $=$ & Proton Nuclear Magnetic Resonance \\
\hline $2 D N M R$ & $=$ & Two-dimension Nuclear Magnetic Resonance \\
\hline ATCC & $=$ & American Type Culture Collection \\
\hline$B H T$ & $=$ & Butylated hydroxytoluene \\
\hline $\operatorname{COSY}$ & $=$ & Correlation Spectroscopy \\
\hline DMSO & $=$ & Dimethylsulfoxide \\
\hline DPPH & $=$ & 1,1-diphenyl-2-picrylhydrazyl radical \\
\hline $\mathbf{E C}_{50}$ & $=$ & Concentration Scavenging 50\% DPPH Radicals \\
\hline EIMS & $=$ & Electron Impact Mass Spectrometry \\
\hline ESI $I^{+}$ & $=$ & Electrospray Ionization \\
\hline FRAP & $=$ & Ferric Reducing Antioxidant Power \\
\hline HMBC & $=$ & Heteronuclear Multiple Bond Connectivities \\
\hline HR-EIMS & $=$ & High Resolution Electron Impact Mass Spectrometry \\
\hline HRMS ESI & $=$ & High-resolution Mass Spectrometry electrospray ionization \\
\hline HSQC & $=$ & The Heteronuclear Single Quantum Coherence \\
\hline IP & $=$ & Institut Pasteur \\
\hline IR & $=$ & Infra-red \\
\hline$M B C$ & $=$ & Minimum bactericidal concentration \\
\hline MFC & $=$ & Minimum fongicidal Concentration \\
\hline MHA & $=$ & Mueller Hinton agar \\
\hline MHB & $=$ & Mueller Hinton broth \\
\hline MIC & $=$ & Minimum inhibitory Concentration \\
\hline MMC & $=$ & Minimum Microbicidal Concentration \\
\hline$N A$ & $=$ & Nutrient Agar \\
\hline NMR & $=$ & Nuclear Magnetic Resonance \\
\hline$R f$ & $=$ & Retention Factor \\
\hline
\end{tabular}




$\begin{array}{lll}\boldsymbol{R O E S Y} & = & \text { Rotating-Frame NOE Spectroscopy } \\ \boldsymbol{S A R} & = & \text { Structure Activity relationship } \\ \boldsymbol{T L C} & = & \text { Thin Layer Chromatography } \\ \boldsymbol{T M S} & = & \text { Tetramethylsilane } \\ \boldsymbol{T O C S Y} & = & \text { Total Correlation Spectroscopy } \\ \boldsymbol{U} \boldsymbol{V} & = & \text { Ultra-violet }\end{array}$

\section{CONFLICT OF INTEREST}

The authors confirm that this article content has no conflict of interest.

\section{ACKNOWLEDGEMENTS}

E.S.F. gratefully acknowledges financial support from DAAD (grant $\mathrm{N}^{\circ}$ A/09/07421) for a scholarship. A.D.N. is grateful to his supervisors Prof. Dr. J. S. Glaser and Dr. R. Marx for helpful suggestions in performing the NMR experiments. Additional financial supports for the work were obtained from the University of Dschang research grant committee and the Cameroonian Ministry of Higher Education special research allocation.

\section{REFERENCES}

[1] Daidone, G.; Maggio, B.; Schillaci, D. Salicylanilide and its heterocyclic analogues. A comparative study of their antimicrobial activity. Pharmazie, 1990, 45(6), 441-442.

[PMID: 2402534]

[2] Franchini, C.; Muraglia, M.; Corbo, F.; Florio, M.A.; Di Mola, A.; Rosato, A.; Matucci, R.; Nesi, M.; van Bambeke, F.; Vitali, C. Synthesis and biological evaluation of 2-mercapto-1,3-benzothiazole derivatives with potential antimicrobial activity. Arch. Pharm. (Weinheim), 2009, $342(10), 605-613$.

[http://dx.doi.org/10.1002/ardp.200900092] [PMID: 19753564]

[3] Pinto, E.; Queiroz, M.J.; Vale-Silva, L.A.; Oliveira, J.F.; Begouin, A.; Begouin, J.M.; Kirsch, G. Antifungal activity of synthetic di(hetero)arylamines based on the benzo[b]thiophene moiety. Bioorg. Med. Chem., 2008, 16(17), 8172-8177. [http://dx.doi.org/10.1016/j.bmc.2008.07.042] [PMID: 18678498]

[4] Daniel, V.P.; Murukan, B.; Kumari, B.S.; Mohanan, K. Synthesis, spectroscopic characterization, electrochemical behaviour, reactivity and antibacterial activity of some transition metal complexes with 2-(N-salicylideneamino)-3-carboxyethyl-4,5-dimethylthiophene. Spectrochim. Acta A Mol. Biomol. Spectrosc., 2008, 70(2), 403-410.

[http://dx.doi.org/10.1016/j.saa.2007.11.003] [PMID: 18165148]

[5] Ghorab, M.M.; Amin, N.E.; El-Gaby, M.S.; Taha, N.M.; Shehab, M.A.; Faker, I.M. Synthesis, antimicrobial, and antitumor activities of some New bisheterocyclic compounds containing biologically active diphenylsulfone moiety. Phosphorus Sulfur Silicon Relat. Elem., 2008, 183, 2918-2928.

[http://dx.doi.org/10.1080/10426500802505440]

[6] Darwish, E.S. Facile synthesis of heterocycles via 2-picolinium bromide and antimicrobial activities of the products. Molecules, 2008, 13(5), 1066-1078.

[http://dx.doi.org/10.3390/molecules13051066] [PMID: 18560329]

[7] Queiroz, M.J.; Ferreira, I.C.; De Gaetano, Y.; Kirsch, G.; Calhelha, R.C.; Estevinho, L.M. Synthesis and antimicrobial activity studies of ortho-chlorodiarylamines and heteroaromatic tetracyclic systems in the benzo[b]thiophene series. Bioorg. Med. Chem., 2006, $14(20)$, 6827-6831.

[http://dx.doi.org/10.1016/j.bmc.2006.06.035] [PMID: 16843669]

[8] Carrillo-Muñoz, A.J.; Giusiano, G.; Ezkurra, P.A.; Quindós, G. Sertaconazole: updated review of a topical antifungal agent. Expert Rev. Anti Infect. Ther., 2005, 3(3), 333-342.

[http://dx.doi.org/10.1586/14787210.3.3.333] [PMID: 15954850]

[9] Chambhare, R.V.; Khadse, B.G.; Bobde, A.S.; Bahekar, R.H. Synthesis and preliminary evaluation of some N-[5-(2-furanyl)-2-methyl-4oxo-4H-thieno[2,3-d]pyrimidin-3-yl]-carboxamide and 3-substituted-5-(2-furanyl)-2-methyl-3H-thieno[2,3-d]pyrimidin-4-ones as antimicrobial agents. Eur. J. Med. Chem., 2003, 38(1), 89-100. [http://dx.doi.org/10.1016/S0223-5234(02)01442-3] [PMID: 12593919]

[10] El-Sharief, S.A.; Micky, J.A.; Shmeiss, N.A.; El-Gharieb, G. Synthesis and reactions of some tetrahydrobenzothieno[2,3-d]pyrimidine derivatives with biological interest. Phosphorus Sulfur Silicon Relat. Elem., 2003, 178, 439-451. [http://dx.doi.org/10.1080/10426500307912]

[11] El-Sherbeny, M.A.; El-Ashmawy, M.B.; El-Subbagh, H.I.; El-Emam, A.A.; Badria, F.A. Synthesis, antimicrobial and antiviral evaluation of certain thienopyrimidine derivatives. Eur. J. Med. Chem., 1995, 30, 445-449. [http://dx.doi.org/10.1016/0223-5234(96)88255-9]

[12] El-Agrody, A.; El-Latif, A.M.; El-Hady, N.; Fakery, A.; Bedair, A. Heteroaromatization with 4-hydroxycoumarin part II: synthesis of some 
new pyrano[2,3-d]pyrimidines, [1,2,4]triazolo[1,5-c]pyrimidines and pyrimido[1,6-b][1,2,4]triazine derivatives. Molecules, 2001, 6 , 519-527. [http://dx.doi.org/10.3390/60600519]

[13] Rositca, D.N.; Vayssilov, G.N.; Rodios, N.; Bojilova, A. Regio- and stereoselective [2 + 2] photodimerization of 3-substituted 2-alkoxy-2oxo-2H-1,2-benzoxaphosphorines. Molecules, 2002, 7, 420-432. [http://dx.doi.org/10.3390/70500420]

[14] Al-Amiery, A.A.; Al-Bayati, R.; Saour, K.; Radi, M. Cytotoxicity, antioxidant and antimicrobial activities of novel 2-quinolone derivatives derived from coumarins. Res. Chem. Intermed., 2011, 38, 559-569. [http://dx.doi.org/10.1007/s11164-011-0371-2]

[15] Al-Amiery, A.A.; Musa, A.Y.; Kadhum, A.A.; Mohamad, A.B. The use of umbelliferone in the synthesis of new heterocyclic compounds Molecules, 2011, 16(8), 6833-6843.

[http://dx.doi.org/10.3390/molecules16086833] [PMID: 21832973]

[16] Kadhum, A.A.; Al-Amiery, A.A.; Musa, A.Y.; Mohamad, A.B. The antioxidant activity of new coumarin derivatives. Int. J. Mol. Sci., 2011, 12(9), 5747-5761. [http://dx.doi.org/10.3390/ijms12095747] [PMID: 22016624]

[17] Kadhum, A.H.; Al-Amiery, A.A.; Sikara, M.; Mohamad, A. Synthesis, structure elucidation and DFT studies of new thiadiazoles. Int. J. Phys. Sci., 2011, 6, 6692-6697.

[18] Kadhum, A.H.; Al-Amiery, A.A.; Aday, H.; Al-Majedy, Y.K.; Al-Temimi, A.A.; Al-Bayati, R.; Mohamad, A. Co-crystal structure of mixed molecules. Int. J. Phys. Sci., 2012, 7, 1564-1570.

[19] Combes, R.D.; Haveland-Smith, R.B. A review of the genotoxicity of food, drug and cosmetic colours and other azo, triphenylmethane and xanthene dyes. Mutat. Res., 1982, 98(2), 101-248. [http://dx.doi.org/10.1016/0165-1110(82)90015-X] [PMID: 7043261]

[20] Chhowala, T.N.; Desai, K.R. Synthesis and studies of eco-friendly acid dye metal complexes and its application on woolen fabrics. IOSR J. Appl. Chem., 2015, 8, 5-10.

[21] (a) Cioanca , E-R.; Carlescu, I; Lisa, G.; Scutaru, D. Synthesis, liquid crystalline properties and thermal stability of 4-(4-alkyloxyphenylazo) benzoic acids. Anal. Univ. Buc. Chim., 2010, 19, 39-46. (serie nouă)

(b) Savchenko, I. Synthesis and electrooptical properties of side-chain polymethacrylates and polycomplexes containing azobenzene moieties with different length spacers. Chemistry \& Chemical Technology, 2014, 8, 383-388.

[22] Fuji, Y.; Hanaki, N.; Fujiwara, T.; Tanaka, S.; Noro, M.; Tateishy, K.; Usami, K.; Hibino, A.; Wachi, N.; Taguchi, T.; Yabuk, Y. Development of high durability cyan and magenta dyes for ink jet printing. Fujifilm Research \& Development, $2009,54,35-42$.

[23] Awad, I.M.; Aly, A.A.; Abdel-Alim, A.M.; Abdel-Aal, R.A.; Ahmed, S.H. Synthesis of some 5-azo(4'-substituted benzene-sulphamoyl)-8hydroxyquinolines with antidotal and antibacterial activities. J. Inorg. Biochem., 1988, 33(2), 77-89. [http://dx.doi.org/10.1016/0162-0134(88)80036-9] [PMID: 3137314]

[24] Makhsumov, A.G.; Normatov, F.A.; Ergashev, M.S.; Garib, F.Y.; Adylov, S.K. Synthesis of certain hydroxyazobenzenes and investigation of their antimicrobial activity. Pharm. Chem. J., 1991, 25, 542-555. [http://dx.doi.org/10.1007/BF00777419]

[25] Ibrahim, S.A.; el-Gahami, M.A.; Khafagi, Z.A.; el-Gyar, S.A. Structure and antimicrobial activity of some new azopyrazolone chelates of $\mathrm{Ni}(\mathrm{II})$ and $\mathrm{Cu}(\mathrm{II})$ acetates, sulfates, and nitrates. J. Inorg. Biochem., 1991, 43(1), 1-7. [http://dx.doi.org/10.1016/0162-0134(91)84063-F] [PMID: 1940898]

[26] Jarrahpour, A.A.; Motamedifar, M.; Pakshir, K.; Hadi, N.; Zarei, M. Synthesis of novel azo Schiff bases and their antibacterial and antifungal activities. Molecules, 2004, 9(10), 815-824. [http://dx.doi.org/10.3390/91000815] [PMID: 18007481]

[27] Samadhiya, S.; Halve, H. Synthetic utility of Schiff bases as potential herbicidal agents. Orient. J. Chem., 2001, 17, 119-122.

[28] Gewald, K. Zur reaktion von $\alpha$-oxo-mercaptanen mit nitrilen. Angew. Chem., 1961, 73, 114-116. [http://dx.doi.org/10.1002/ange.19610730307]

[29] Gewald, K. Heterocyclen aus CH-aciden nitrilen, VII. 2-amino-thiophene aus $\alpha$-oxo-mercaptanen und methylenaktiven nitrilen. Chem. Ber., 1965, $98,3571-3577$.

[http://dx.doi.org/10.1002/cber.19650981120]

[30] Ried, W.; Nyiondi, B.E. Ûber die gemeinsame einwirkung von schwefel und methylenaktiven nitrilen oder ammoniak auf 2hydroxyacetophenon. Liebigs Ann. Chem., 1973, 1, 134-140. [http://dx.doi.org/10.1002/jlac.197319730119]

[31] (a) Fondjo, S.E.; Döpp, D.; Henkel, G. Reactions of some annelated 2-aminothiophenes with electron poor acetylenes. Tetrahedron, 2006, 62, 7121-7131. [http://dx.doi.org/10.1016/j.tet.2006.04.037]

(b) Fondjo, S.E.; Tsemeugne, J.; Sondengam, B.L.; Oppenlaender, T.; Kamdem, W.H.; Tane, P.; Connolly, J.D.; Wim, D.; Taoufik, R.; Haruhisa, K.; Yoshiteru, O. Coupling of Two Diazotized 3-Aminothieno[3,4-c]coumarins with Aromatic Amines. J. Heterocycl. Chem., 2011, 48, 1295-1301.

[http://dx.doi.org/10.1002/jhet.757] 
[32] Atta-Ur, -Rahman Chapter 1: Chemical Shifts in 1H-NMR Spectroscopy. In Nuclear Magnetic Resonance, Basic Principles;; Springer-Verlag: New York Inc, 1986, pp. 24-5.

[33] Atta-Ur, -Rahman Chapter 4: Chemical Shifts and Spin-Spin Couplings in 13C-NMR Spectroscopy. In Nuclear Magnetic Resonance, Basic Principles;; Springer-Verlag: New York Inc, 1986, pp. 140-6.

[34] Atta-Ur, -Rahman; Choudhary, I.M. Chapter 7: Recent Developments in NMR Spectroscopy. In Solving Problems with NMR Spectroscopy; Academic Press, Inc.: San Diego: California, 1996, pp. 273-5.

[35] Atta-Ur, -Rahman; Choudhary, I.M. Chapter 7: Recent Developments in NMR Spectroscopy. In Solving Problems with NMR Spectroscopy; Academic Press, Inc.: San Diego: California, 1996, pp. 376-7.

[36] Amir, M.; Alamkhan, S.; Drabo, S. Synthesis and antibacterial activity of 4-arylazo-1-substituted-3,5-diphenylpyrazoles. J. Indian Chem. Soc., 2002, 79(3), 280-281.

[37] Dhingra, V.; Bhatwadekar, R.; Pendse, S. Synthesis and biological activity of some 1-isonicotionoyl-3,5- diphenyl-4-4 substituted phenyl azo pyrazoles. Asian J. Chem., 1993, 5, 515-518.

[38] Djouossi, M.G.; Tamokou, J.D.; Ngnokam, D.; Kuiate, J.R.; Tapondjou, A.L.; Harakat, D. Laurence- Nazabadioko, L.V.: Antimicrobial and antioxidant flavonoids from the leaves of Oncoba spinosa Forssk (Salicaceae). BMC Complement. Altern. Med., 2015, 15(134), 1-8. [PMID: 25617057]

[39] Li, Y.; Guo, C.; Yang, J.; Wei, J.; Xu, J.; Cheng, S. Evaluation of antioxidant properties of pomegranate peel extract in comparison with pomegranate pulp extract. Food Chem., 2006, 96(2), 254-260. [http://dx.doi.org/10.1016/j.foodchem.2005.02.033]

[40] Kumar, K.C.; Keshavayya, J.; Rajesh, T.; Peethambar, S.K. Synthesis, characterization and biological activity of heterocyclic azo dyes derived from 2-aminobenzothiozole. Int. J. Pharm. Pharm. Sci., 2013, 5(1), 296-301.

[41] Fogue, P.S.; Lunga, P.K.; Fondjo, E.S.; De Dieu Tamokou, J.; Thaddée, B.; Tsemeugne, J.; Tchapi, A.T.; Kuiate, J-R. Substituted 2aminothiophenes: antifungal activities and effect on Microsporum gypseum protein profile. Mycoses, 2012, 55(4), $310-317$. [http://dx.doi.org/10.1111/j.1439-0507.2011.02089.x] [PMID: 21831103]

[42] Metwally, M.A.; Suleiman, Y.A.; Gouda, M.A.; Harmal, A.N.; Khalil, A.M. Synthesis, antitumor and antioxidant evaluation of some new antipyrine based azo dyes incorporating pyrazolone moiety. Int. J. Mod. Org. Chem., 2012, 1(3), 213-225.

[43] Nyaa, T.B.; Tapondjou, A.L.; Barboni, L.; Tamokou, J.D.; Kuiate, J.R.; Tane, P.; Park, H. NMR assignment and antimicrobial/antioxidant activities of $1 \beta$-hydroxyeuscaphic acid from the seeds of Butyrospermum parkii. J. Nat. Prod. Sci., 2009, $15,76-82$.

[44] Tamokou, Jde.D.; Kuiate, J.R.; Tene, M.; Kenla Nwemeguela, T.J.; Tane, P. The antimicrobial activities of extract and compounds isolated from Brillantaisia lamium. Iran. J. Med. Sci., 2011, 36(1), 24-31. [PMID: 23365474]

[45] Padmaja, M.; Sravanthi, M.; Hemalatha, K.P.J. Evaluation of antioxidant activity of two Indian medicinal plants. J. phytol., 2011 , 3(3), 86-91.

(C) Sopbue Fondjo et al.; Licensee Bentham Open.

This is an open access article licensed under the terms of the Creative Commons Attribution-Non-Commercial 4.0 International Public License (CC BY-NC 4.0) (https://creativecommons.org/licenses/by-nc/4.0/legalcode), which permits unrestricted, non-commercial use, distribution and reproduction in any medium, provided the work is properly cited. 